\title{
Food Fraud and Its Liability in North Cyprus Law
}

\author{
Aysun Beydola \\ Yakin Dogu University, Lefkosa, KKTC \\ E-mail: av.aysunbeydola@gmail.com \\ Ozlem Rodoplu \\ E-mail: ozlemrodoplu@gmail.com
}

\begin{abstract}
It is compulsory for the mankind to consume food in order to survive. Consumption of unhealty food causes increased diseases and poses risk to public health. Today, there are cheats in food for the sake of making more money. In this study, the food fraud in North Cyprus, the responsibility of people cheating in food and the necessary method that can be followed to prevent food fraud is been examined. This study is of great importance in terms of being the first study written in the field of food law in North Cyprus.
\end{abstract}

Keywords: Food Safety, Food Fraud, Food Control.

Special Issue of Health Sciences

DOI: $10.7176 /$ JSTR/6-03-15

\section{Kuzey Kıbrıs Hukukunda Gıdada Hile ve Gıdada Hile Yapılması Halinde Sorumluluk}

\begin{abstract}
Özet
İnsanoğlunun yaşamını idame ettirebilmesi için gıda tüketmesi zorunludur. Sağlıklı olmayan gıda tüketimi hastalıkların artmasına neden olmakta ve kamu sağlı̆̆ tehlike altına girmektedir. Maddi çıkarlar doğrultusunda, daha fazla para kazanmak uğruna günümüzde gıdalarda hileler yapıldı̆̆ı görülmektedir. Bu çalışmada Kuzey Kıbrıs hukukunda gıdalarda yapılan hileler, gıdada hile yapan kişilerin sorumluluğu ve bu hilelere engel olmak adına nasıl bir mücadale yöntemi izlenebileceği hususları izah edilmeye çalışılmıştır. Bu çalışma Kuzey Kıbrıs'da gıda hukuku alanında yazılmış ilk çalışma olması anlamında büyük önem taşımaktadır.
\end{abstract}

Anahtar Kelimeler: Gıda Güvenliği, Gıdada Hile, Gıda Denetimi.

\section{Giriş}

Gıda, insanın yaşamını idame ettirmesi için ihtiyaç duyduğu, olmazsa olmaz olarak nitelendirebileceğimiz en önemli gereksinimlerden biridir. Gıda güvenliği amaçları doğrultusunda üretildiğinde veya tüketildiğinde gıdanın tüketiciye zarar vermeyeceği süreç olarak ifade edilebilir (Kantaroğlu, M., Demirbaş, N., 2019). Dünya Sağlık Örgütü (WHO), Gıda Tarım Örgütü (FAO) ve Codex Alimentarius Uzmanlar Komisyonu gida güvenliğini şu şekilde izah etmektedirler. Buna göre gıda güvenliği, sağlıklı ve kusursuz gıda üretimi sağlamak amacıyla gıdaların üretim, işleme, muhafaza, taşıma ve dağıtım aşamalarında gerekli kurallara uyulması ve önlenmelerin alınmasıdır (FAO and WHO, 2015). Güvenli olmayan gıda ile beslenme sonucunda son zamanlarda ortaya çıkan salgın hastalıklar ve diğer hastalıkların gitgide artması güvenli gıda tüketiminin ne kadar önemli olduğunu ortaya koymaktadır. Üretim zincirinin her halkasının sağlam olması ile ancak güvenli gıda üretimi mümkün 
olabilecektir. Bu zincirin herhangi bir halkasında ya da sistemin herhangi halkasında meydana gelen aksaklıklar gıdanın güvenliğini tehlikeye atacaktır (Tayyar, 2014).

Bu çalışmada, gıdada hile, gıdada hilenin gerçekleştirilmesi yolları ve gıdada hile yapılması durumunda uygulanacak yaptırımlar üzerinde durulacaktır. Güvenli gıda tüketimi hususunun önemine rağmen Kuzey Kıbrıs'da konu hukuki açıdan ele alınıp çalışılmamıştır. Bu çalışma, Kuzey Kıbrıs'da bu konuda yazılmış ilk hukuki çalışmadır.

\section{Tanım}

Gıdada hilenin ne anlama geldiği hususunda öncelikle bazı terimlerin açıklanması gerekmektedir. Bu terimler konusunda hukukumuzda düzenlemeler Veteriner Hizmetleri Kanunu'nda ve Gıda Maddeleri Ve İlaçların Satışı Yasası'nda yer almaktadır. Buna göre gıda insanlar tarafından yenilen, içilen veya insanlara yenilmesi, içilmesi için sunulan, tüketilmesinde hastalık riski oluşturma ihtimali olan işlenmiş, kısmen işlenmemiş veya işlenmemiş hayvansal gıdadır (Veteriner Hizmetleri Yasası İç Düzeni m. 2). Gıda Maddeleri Ve İlaçların Satışı Yasası'nda ise gıda maddesinin ne ifade ettiği açıklanmıştır. Buna göre gıda maddesi ilaç ve su dışında, insanlar tarafından yiyecek veya içecek olarak kullanılan her maddedir ve mutad olarak insan yiyeceklerine konan veya insan yiyeceklerinin terkibinde veya hazırlanmasında kullanılan herhangi bir maddedir. Aynı zamanda tatlandırıcı maddelerle tuz, baharat, hardal v.s. gibi çeşni verici katkı maddeleridir (m. 2).

Tağşiş ürünlere temel özelliğini veren öğelerin ve besin değerlerinin tamamının veya bir bölümünün mevzuata aykırı olarak çıkarılması veya miktarının değiştirilmesi ya da aynı değeri taşımayan başka bir maddenin, o madde yerine aynı madde gibi katılması olarak ifade edilebilir. Gıda Maddeleri ve İlaçların Satışı Yasası m. 9/2‘de tağşş̧in ne ifade ettiği ortaya konmuştur. Buna göre bir gıda maddesi, niteliğini, özünü veya kalitesini zarara uğratacak biçimde başka bir maddeyle karıştırıldığında veya gıda maddesini meydana getiren herhangi bir kısım içinden çıkarıldığında tağşiş edilmiş veya gıda değeri zayıflatılmış olur.

Taklit ise ürünlerin, şekil, bileşim ve nitelikleri itibariyle yapısında bulunmayan özelliklere sahip gibi veya bir başka ürünün aynısıymış gibi gösterme olarak ifade edilebilir. Gıda maddesi alıcının talep ettiği özde değilse yani bir başka madde gibi satılıyorsa gıdada taklitten bahsedilebilecektir (Gıda Maddeleri ve İlaçları Satışı Yasası m. 4).

\section{Gıdada Hilenin Gerçekleştirilmesi Yolları}

\subsection{Gıdada Hilenin Tağşiş Suretiyle Gerçekleştirilmesi}

\subsubsection{Gıda Maddelerinin Başka Maddelerle Karıştırılması Veya Gıda Maddelerinden Gıda} Maddesinin Niteliğine, Özüne Yada Kalitesine Zarar Verecek Şekilde Eksiltme Yapma

Herhangi bir gıda maddesinin satmak amacıyla sağlığa zararlı hale getirilecek şekilde herhangi bir harç veya madde ile karıştırılmışsa, renklendirilmişse, boyanmışsa, ögütülüp toz halinde getirilmişse gıdada hile gerçekleştirilmiş demektir (Gıda Maddeleri ve İlaçların Satışı Yasası m. 3/1). Bu yolla ortaya çıkmış bir ürünün yapılmasına emir verilmesi, izin verilmesi veya satılması yasal düzenleme ile yasaklanmıştır (Gıda Maddeleri ve İlaçların Satışı Yasası m. 3/2).

Bir gıda maddesinde koruyucu madde veya başka bir harcın eklenmesi yasal bir düzenleme ile yasaklanmışsa, bu yasağa rağmen koruyucu madde veya başka bir harç ekleme yapılmışsa o ürünün sağlığa zararlı hale geldiği kabul edilmektedir (Gıda Maddeleri ve İlaçların Satışı Yasası m. 3/m. 3(a)).

Gıda maddesinin niteliğine, özüne veya kalitesine zarar verecek şekilde değiştirilmesi, eksiltilmesi gıdada hile yapmak anlamına gelir (Gıda Maddeleri ve İlaçların Satışı Yasası m. 7).

Gıda maddesine başka madde katmak suretiyle tağşiş suretiyle hile örnekleri aşağıda yer almaktadır (Anonim A, 2020):

$>$ Tereyağına bitkisel yağ karıştırılarak satılması,

$>$ Yoğurda peynir, yoğurt, kaymak ve tereyağı ürünlerine bitkisel yağ, nişasta, natamisin katılması katılmas1,

$>$ Zeytinyağına tohum yağlarının karıştırılması,

$>$ Üzüm pekmezine glukoz şurubu, inülin, fruktoz ilavesi,

Bala glikoz ve fruktoz şurubu katılması,

$>$ Un üretiminde süneli, böcek yeniği, aflatoksinli ve/veya soya bulaşması olan buğdayların kullanılması,

$>$ Baharatın içine irmik, kepek, razmol, kiremit tozu, renklendirici vb. katılması,

$>$ Bulgur, makarna, tatlı biber salçası üretiminde boya kullanılması, 
$>$ Takviye edici gıdalarda ve özellikle zayıflama için tüketilenlerde sildenafil, tadalafil ve sibutramin içermesi,

$>$ Çikolata ve enerji içecekleri gibi ürünlere ilaç etken maddesi olan sildenafil, tadalafil, kinidin kat1lmas1,

$>$ Üzüm pekmezine incir ekstraktı ilavesi

$>$ Natürel zeytinyağına farklı cins bitkisel kökenli meyve veya tohumlardan elde edilen yağların (kanola, ayçiçek, soya, pamuk, mısır, avakado vb.) ilavesi birer tağşiş örneğidir.

> Gazlı içeceklere ve enerji içeceklerine ilaç etken maddesi olan sildenafil katılması,

$>$ Çaya boya gıda maddesi katılması,

$>$ Dövülmüş fistık içine yer fistığı katılması, dökme antep fistığı içine yer fistığı katılması.

$>$ Ballı bitkisel karışımlara, epimedyumlu macuna, enerji içeceklerine, kuvvet macununa ilaç maddesi olan sildenafil veya parasetamol katılması.

Kırmızı et ve et ürünlerinde ise tağşiş örnekler aşağıda yer almaktadır:

$>$ Domuz, at ve eşek etinin katılması,

$>$ Beyan dışında kanatlı eti katılması,

$>$ Beyan dışında hindi, bıldırcın veya devekuşu etinin katılması,

$>$ Baş eti katılması, tek tırnaklı eti tespiti

$>$ Köftelerde beyan dışında farklı tür et katılması veya sakatat, baş eti katılması, deri dokusu tespiti.

$>$ Köftelerde hayvansal olmayan proteinler, nişasta, soya ve soya ürünleri kullanılması kırmızı et ve et ürünlerinde somut tağşiş örnekleridir.

Yapılan denetimler ve çalışmalar sonucunda; hilenin en çok zeytinyağı, süt ve süt ürünleri, bal, et ve et ürünleri, gıda takviyelerinde olduğu görülmektedir (Doğan, 2019).

\subsubsection{Niteliği Veya Kalitesi Talep Edilene Uymayan Gıda Maddelerinin Satılması}

Alıcının talep ettiği nitelikte ve kalitede olmayan gıda maddesinin satılması yasal düzenlemelerle yasaklamıştır ve gıdada hile olarak nitelendirilir (Gıda Maddeleri ve İlaçların Satışı Yasası m. 4 (1)).

Sağlığa zararlı olmayan harç veya malzeme gıda maddesine ticari meta olarak nakliye veya tüketime elverişli durumda üretilmesi veya hazırlanması için gerekli ise eklenebilir. Her halûkarda eklemede amaç gıda maddesinin veya ilacın hacminin, ağırlığının veya ölçüsünün hile ile çoğaltılması olmamalıdır (Gıda m. 4 (2)). Yine gıda yürürlükteki patente konu ise ve patentin içerdiği spesifikasyonların gerektirdiğ durumda arz edilmişse ve gıda maddesinin toplanma ve hazırlanma sürecinde yabancı maddelerle karıştırılması kaçınılmazsa gereği yapılabilir ve herhangi bir sorumluluk gündeme gelmez (Gıda Maddeleri ve İlaçların Satışı Yasası m. 4 (2)).

\subsubsection{Bozulmuş Gıda Maddesi Satma}

İnsanlar tarafından yenilmeye veya tüketilmeye elverişli olmayacak ölçüde tamamen veya kısmen bozulmuş, çürümüş, erimiş gıda maddesini satmak gıdada hile yapmak anlamına gelmektedir ve bu nitelikte gıda maddesini satmak, satış için teşhir veya teklif etmek, başkasının satmasına, satış için teşhir veya teklif etmesine emir veya izin vermek, ya da bu nitelikte bir gida maddesinin tasarrufta bulundurmak ilgili kişinin sorumluluğunu doğuracaktır (Gıda Maddeleri ve İlaçların Satışı Yasası m. 8).

\subsection{Gıdada Hilenin Taklit Suretiyle Gerçekleștirilmesi}

Bir maddeyi şekil, bileşim ve nitelikleri itibarı ile yapısında bulunmayan özelliklere sahip gibi göstermeye, başka bir maddeye benzetmeye çalışmak gidada hilenin taklit suretiyle gerçekleştirilmesi anlamında gelir (Özen 2016). Hukukumuzda gıdada taklit terimi ile açık olarak ifade edilmese de Gıda ve İlaçların Satışı Yasası m. 7 ve 4'den gıdada taklitin hile olarak kabul edileceği sonucu çıkarılabilecektir. Gıda maddesinin özü değiştirilmiş bir başka maddeye benzetilmeye çalışılmışsa gıdada taklitten bahsedilecektir (Gıda ve İlaçların Satışı Yasası m. 4, m. 7). Gıdada taklit yapmak suretiyle hilenin gerçekleştirildiği örnekler aşağıda yer almaktadır (Anonim A, 2020.; Artık, N. 2020).

$>$ Meyve şurubunun üzüm pekmezi olarak pazarlanması,

$>\quad$ bitkisel kökenli bir yağın aromalarla ve katkı maddeleri ile tereyağına benzetilerek tereyağı olarak satılması,

$>$ Antep fistığı yerine bezelye veya yer fistığının öğütülüp boyanarak Antep fistığı olarak kullanılmasi,

$>$ Kusurlu ham yağların fiziksel ve kimyasal yöntemlerle üretilen rafine zeytinyağına \%1 -10 arasında natürel sızma zeytinyağı ilave edilmesi ve natürel sızma zeytinyağı olarak satışa sunulması,

$>$ Isıl işlem görmüş sucukların ısıl işlem uygulanmamış fermente sucuk olarak etiketlenmesi ve 
satışa sunulması,

$>$ Arısız bal üretiminde misır şurubuna bal enzimi katılması,

$>$ Doğal kaymaklı yoğurda jelatin katılması,

$>$ Keçi ezine peynirinin tamamının veya bir kısmının inek sütü ve/veya koyun sütü ile yapılmasidir.

\section{Gıdada Hile Yapılması Halinde Sorumluluk}

\subsection{Hukuki Sorumluluk}

Gıda maddesinde hile yapılması durumunda hile yapan kişinin haksız fiil sorumluluğu ortaya çıkabileceği gibi, gıda maddesinde hile yapıldığı hususunda zarar verici yalan söyleyen kişinin de koşulların oluşması halinde haksız fiil sorumluluğu doğacaktır (Haksız Fiil Yasası m. 25).

Gıda ürünlerinde hile yapılması halinde gıda maddesinin satılması sonucunda, üçüncü kişiler zarara uğramışsa haksız fiile dayalı dava açılabilecektir (Haksız Fiil Yasası, Fasıl 148)). Haksız Fiiller Yasası bağlamında hile bir gerçeğin veya olgunun, gerçek olduğu bilinci içinde veya doğru olduğuna inanılmaksızın ya da kayıtsızca veya doğru ya da gerçek dışı olup olmadığına özen gösterilmeden, aldatılan veya kandırılan kişinin ona göre işlem veya eylemde bulunması niyetiyle yaptığı gerçek dışı ifadesidir (m. 36). Haksız fiil sorumluluğunun doğabilmesi için gerçekleşmesi gereken koşul vakıalar hukuka aykırı fiil, zarar ve illiyet bağıdır. Burada hukuka aykırı fiili oluşturan koşul vakıa gıdada hile yapılmasıdır. Gıdada hile yapılması nedeniyle haksız fiile dayalı tazminat davası açılabilmesi üreticinin davacıyı aldatmak veya kandırmak niyetinde olması durumunda açılabilir. Ayrıca bu fiil sonucu tüketici aldanmış ve kanmış olmalı ve zarara uğramalıdır (m. 36/2). Zarar gören kişi gıdada hile yapılması sonucunda zarar gördüğünü yani aradaki illiyet bağını mahkeme huzurunda ispatlaması halinde tazminat almaya hak kazanabilecektir.

Gıda maddesinde herhangi bir hile yapılmamasına rağmen gıda maddesi hakkında hile yapılmış gibi gerçeğe aykırı bir beyanda bulunulursa veya bu beyan yayımlanırsa zarar verici yalan adı verilen haksız fiil oluşur ve üretici emtiası hakkında zarar verici yalan nedeniyle zarara uğramışsa tazminat talebiyle dava açabilecektir (Haksız Fiiller Yasası m. 25/2 (a)). Üretici gıda maddesi hakkında hile beyanı üreticiyi parasal zarar uğratmak amacıyla kullanılmışsa ve yazılı veya kalıcı bir şekilde yayımlanmışsa üretici zarar görmese de tazminat davası açabilecektir. Yine gıdada hile yapıldığı konusunda yalan beyanda bulunan kişinin bu beyan ile amacı üreticinin parasal kayba uğraması üretici herhangi bir zarara uğramasa da bu kişiye karşı tazminat davası açabilecektir (Haksız Fiil Yasası m. 25/2 (b) ).

\subsection{Kabahat Sorumluluğu}

Gıdada hile yapanlara ilk defa bu fiili gerçekleştirmesi halinde elli lira idari para cezası verilir (Gıda Maddeleri ve İlaçların Satışı Yasası m. 4). İkinci kez bu fiilin gerçekleştirilmesi halinde ise fiili gerçekleştiren kişinin kabahat sorumluluğu yanında cezai sorumluluğu ya da tek başına cezai sorumluluğu gündeme gelecektir. Yasa eski bir yasa olup, ivedilikle tadil edilmelidir; zira bu para cezası günümüz koşullarına uygun değildir ve çok düşüktür. Gida güvenliğinin bulunmaması kamu sağlı̆̆ııı etkileyeceğinde cezaların caydırıcı olması büyük önem taşımaktadır.

\subsection{Cezai Sorumluluk}

Gıda Maddeleri ve İlaçların Satışı Kanunu'nda yer alan kuralların herhangi birine aykırı davranan kişiler yani gıda maddesinde hile yapan kişiler ilk kez bu fiili gerçekleştirmişlerse 50 lira para cezasına mahkum edileceklerdir (Gıda Maddeleri ve İlaçların Satışı Yasası m. (3) ). İkinci kez gıda ile ilgili bir suç işlenmesi halinde ceza yine aynı yasada tespit edilmiştir. Buna göre ilgili kişi altı aya kadar hapis cezasına veya elli liraya kadar para cezasına veya her iki cezaya birden çarptırılabilecektir (Gıda Maddeleri ve İlaçların Satışı Yasası, m. 3 (b)).

Gıdada hile suçu 6 farklı şekilde işlenebilir. Suçun 6 farklı şekilde işlenebilecek olması, seçimlik hareketli haksızlık olduğunu ortaya koymaktadır. Suçun işleniş biçimleri yasaklanmış veya kısıtlanmış koruyucu maddenin veya başka harcı gıda maddesine eklenmesi, satın alıcının talep ettiği nitelikte, veya özde veya kalitede olmayan herhangi bir gıda maddesini veya ilacı alıcıya halel verecek biçimde satılması (Gıda Maddeleri ve İlaçların Satışı Yasası, m. 4), bir gıda maddesinin herhangi bir kısmını, o gıda maddesinin niteliğine, özüne veya kalitesine zarar verecek şekilde ve böylece değiştirilmiş haliyle, değiştirildiğine dair bildirimde bulunmaksızın, satmak niyetiyle gıda maddesinden çıkarılması veya bu şekilde değiştirilmiş bir gıda maddesinin değişikliği açıklanmaksızın satılması (Gıda Maddeleri ve İlaçların Satışı Yasası, m. 7) dır. Bir diğer suçun işleniş biçimi insanlar tarafından yenilmeye veya tüketilmeye herhangi bir nedenle elverişli olmayacak ölçüde tamamen veya kısmen bozulmuş veya erimiş veya çürümüş herhangi bir gıda maddesini veya ilacı satılması veya satış için teşhir veya teklif 
edilmesi veya başka bir kişinin satmasına ya da satış için teşhir veya teklif etmesine emir veya izin verilmesi veya böyle bir gıda maddesini satmak amacıyla tasarrufta bulunmaktır (Gıda Maddeleri ve İlaçların Satışı Yasası, m. 8). Söz konusu seçimlik hareketlerden en az birinini işlenmesi gıdada hile filiinin gerçekleşmesi için yeterli kabul edilecek ve cezai sorumluluk doğacaktır. Gıdada hilenin gerçekleşmiş sayılabilmesi için yani cezai sorumluluğun doğabilmesi için kasten hareket edilmesi gerekmez; zira korunmak istenen yarar kamu sağ lı̆̆ıdır. Bu nedenle bu suç kasten veya taksirle işlenebilir (Özen, 2016).

Cezasızlık halleri ise eklemenin tüzükte belirtilen sınırı aşmaması ve gıda maddesinin veya ilacın karıştırılmış, renklendirilmiş, boyanmış veya toz haline getirilmiş olduğunun bilinmemesi veya makûl ölçüde çaba göstermiş olsa da bilmesinin olanaksız olması ve bu hususun da mahkeme huzurunda kanıtlanmasıdır (Gıda Maddeleri ve İlaçların Satışı Yasası, m. 3 (b)).

Diğer cezasızlık halleri ise sağlığa zararlı olmayan bir harcın veya malzemenin gıda maddesine veya ilaca, o gıda maddesinin veya ilacın hacminin, ağırlığının veya ölçüsünün hile ile çoğaltılması veya düşük kalitesinin gizlenmesi amaciyla değil de bir ticari meta olarak nakliyeye veya tüketime elverişli bir durumda üretilmesi veya hazırlanması için gerekli olduğu nedeniyle eklenmesi halidir. Bu durumda ilgili kişi cezalandırılamaz.

Yine gıda veya ilacın, yürürlükte olan bir patente konu olduğu ve patentin içerdiği spesifikasyonların gerektirdiği durumda arzedildiği, veya bir ilacın bir özel kişi veya firma tarafından ticari unvanı (brand) altında arzedilen bir ilaç olduğu durumlarda, gıda maddesinin veya ilacın, toplanma veya hazırlanma sürecinde bazı yabancı maddelerle karışmasının kaçınılmaz olduğu durumlarda fiili gerçekleştiren kişi cezalandırılamaz ( Gıda Maddeleri ve İlaçların Satışı Yasası, m. 4).

\section{Gıdada Hile Yapılmasına Engel Olabilmek İçin Başvurulabilecek Mücadele Yöntemleri}

Gıdada hile son 30 yıllık süreçte gıda tedarik zincirlerinin küreselleşmesi ve karmaşık yapıya bürünmesi nedeni ile büyük oranda artmıştır (Moore, J. C., Spink, J., Lipp, M., 2012). Bununla doğru orantılı olarak gıda kaynaklı hastalıkların ortaya çıkma riski de artmış ve güvenli gıda için mücadale etme gereği kuvvetlenmiştir. Gıdada hile ile mücadale adına gıdaların üretimi ve denetlenmesine önem verilmesi ve özen gösterilmesi büyük önem taşımaktadır. Güvenli gıda üretmeyen gıdada hile yapan işletmelere en ağır olacak şekilde caydırıcı ceza verilmelidir.

Gıda işletmelerinde gıda bilimi konusunda eğitim görmüş kişiler sorumlu yönetici olarak ve eleman olarak çalıştırılmalıdır (Batu, A., Akbulut, M., Kırmacı, B., Elyıldırım, F. 2007). Yasal düzenlemeler gözden geçirilmelidir ve para cezalarının miktarı tâdil edilip, caydırıcı olacak nitelikte yeniden düzenlenmelidir ve hapis cezası için suçun yeniden işlenmesi unsuru aranmamalıdır; zira tehdit altında olan bir kişinin değil o ürünü kullanan herkesin, halkın sağlığıdır.

Gıdada hile yapılmışsa ve bu gıda tüketilmişse, tüketicinin sağlığı büyük bir tehdit altına girmiş demektir. Hileli gıda tüketilmesi sonucu ortaya çıkacak olumsuz etkiler bazen hemen, bazı durumlarda ise zamanla ortaya çıkmaktadır. Örneğin; Çin'de bebek mamalarında kullanılan süt tozlarına karıştırılan melamin sebebiyle 300 bin bebek zehirlenmiştir ve bu bebeklerden altısı ölmüştür (Anonim B, 2010).

Hileli gıdaların ortaya çıkardığı olumsuz etkilerin bazıları ise zamanla ortaya çıkmaktadır. Uzun vadede çok feci sonuçlar gündeme gelebilmektedir. Örneğin gıdadan bulaşan bazı toksik kimyasal maddelerin, ağır metallerin neden olduğu rahatsızlıklar uzun vadede açığa çıkmaktadır. Gıdada hile sonucu ortaya çıkan etkilerin tam olarak tespit edilememesi bazı durumlarda hemen bazı durumlarda ise zamanla ortaya çıkması sebebiyle küresel ölçekte gıda kaynaklı hastalıklar ve ölümlerin net bir şekilde istatistiğ çıkarılamamaktadır (Doğan, O., 2019). Ancak, Dünya Sağlık Örgütü (WHO) çalışmaları güvenli olmayan gıdaların taşıdıkları zararlı bakteriler, parazitler, virüsler veya kimyasal maddelere bağlı 200'den fazla farklı hastalık tespit etmiştir. En önemli nokta ise bu çalışmalarda her yıl yaşanan genç ölümlerin yaklaşık \%2'sinin gıda kökenli rahatsızlıklardan kaynaklandığının ortaya konmasıdır (WHO, 2015). İşin bu kadar hassas ve ciddi olması denetimlerin sık ve titizlikle yapılması zorunluğunu ortaya çıkarmaktadır. Denetim mekanizması etkin bir biçimde çalışmalıdır.

Yalnızca denetim mekanizmasının etkin çalışması da tek başına yeterli olmayacaktır. Gıda sektöründe çalışan, tüketici sağlı̆̆ını yaptığı işin mahiyeti sonucunda direkt etkileyen tüm personelin "gıda güvenliği’" hususunda eğitim almaları önemlidir.

Hileli gıdaların varlığı, tüketici gözünde kimi zaman tüm bir sektörü ya da gıda kategorisi hakkında halkta olumsuz bir önyargı oluşmasına sebep olmuştur. İşinin düzgün yapan firmaların da bulunduğu unutulmamalıdır. Aksi halde tüm sektör büyük zarar görecektir (Anonim C, 2017). Hatta ilgili gıda tüketimi bile durabilecektir. Örneğin yakın bir tarihte sspanak içerisine yabani otun karışması ile yaşanan zehirlenme olayı neticesinde kamuoyunda bir süre 1spanak tüketimi azalmıştır. Bu nedenle üreticilerin bilinçli ve yasal şartlara uygun üretim gerçekleştiriyor olması tüketici sağlığının korunması için son derece önemlidir (Anonim D, 2019). 
Diğer sektörlerde olduğu gibi, gıda sektöründe de yasal şartlara uymayan firmalar olduğu gibi, gıda güvenliğine son derece önem veren, örnek nitelikte ürünler üreten firmaların da var olduğunu unutmamak gerekir.

Firmaların yasal sorumluluklarını yerine getirmesi taklit ve tağşiş açısından yine de yeterli değildir. Kasıtlı olarak gıdaya hile yapılmasının yanı sıra firmaların farkındalık eksikliği nedeniyle üretim prosesinde gıda güvenliğine dikkat etmemesi sonucu da taklit ve tağşiş riski ortaya çıkmaktadır. Örneğin Et parçalama veya işleme tesisinde bıçakların temizlik ve dezenfeksiyonuna dikkat edilmemesi, sakatat işlenen bir bıçağın parçalama ve işleme alanında dezenfekte edilmeden kullanılması ile üründe sakatat bulaşması yapabilmektedir.

Yasal limitlerle sınırlandırılan katkı maddesi kullanımı yine gıda üretiminde çalışan personelin, katkı maddesini belirlenen oranların üstünde kullanması sonucu gıdada istenmeyen tüketici sağlığını riske atan durumlarla karşılaşılmasına sebebiyet vermektedir.

Sebebi her ne olursa olsun; kasıtlı veya bilinç eksikliği nedeniyle gıdanın tüketici sağlığını tehtid etmesinin önüne geçebilmek için ilgili kurumların etkin denetim mekanizması ve caydırıcı cezalarıyla yaptırımda bulunmaları önem arz etmektedir.

Gıdada hile yapılmasına engel olmak için en etkili mücadele yöntemlerinden biri de Sağlık Bakanlığ tarafından kamuoyunun bilgilendirilmesi olacaktır. Gıda Güvenliği Bilgi Sistemi’nin kurulması, riske dayalı denetim sistemine geçilmesi gibi çalışmalar yapılmalıdır. Bu sistemin kurulması sonrasında denetimlerde gıda maddesinin içerisinde bulunmaması gereken ilaç etken maddesi bulunması durumları, gıda hilesi kapsamında Gıda Güvenliği Bilgi Sistemi'nde değerlendirilebilecek ve bu ürünleri üreten işletme veya şirketler teşhir edilebilecektir (Özen, 2016). Bu sayede daha etkili ifade ile teşhir edilmek korkusu ile üreticiler daha gıda güvenliği hususunda daha dikkatli davranacaklardır. Kuzey Kıbrıs nüfusunun azlığı düşünüldüğünce küçük bir yerde teşhir edilmek üreticinin büyük bir prestij kaybına neden olacaktır. Bu yönde alınacak tedbir en etkili tedbirlerden biri olacaktır.

Sağlık Bakanlığı'nda denetçi kadrosu artırılmalıdır. Bu kadroda alanında uzman kişiler istihdam edilmelidir.

Kuzey Kıbrıs'da Sağlık Bakanlığı gıda maddeleri üzerinde her ay düzenli denetimler gerçekleştirmekte ve aylık, yıllık denetim sonuçlarını yani istatistiksel olarak açıklamaktadır (Anonim E, 2020). Yayınlanan 2018 yılı faaliyet raporunda 2018 yılı içerisinde 1324 işyeri denetlenmiş olup gıda güvenliğ açısından risk oluşturan 24490 adet gıda maddesi imha edilmiştir. Ayrıca bu zaman dilimi içinde tüm adada mevcut 55 ekmek firınından çeşitli numuneler alınıp tuz miktarları ve mikrobiyolojik olarak yasaya uygunlukları denetlenmiştir (Anonim F, 2020).

2019 Ekim ayında gıda ve ambalajlanmış içme suyu üretim yerleri ile toplu tüketim yerlerinden otel, restoran, büfe, okul mutfağ1, okul kantini, fırın, pastane, alkollü ve alkolsüz içki üreten fabrikalar vb. 83 tanesi gıda güvenliği bakımından denetlenmiştir. Denetleme sonucunda toplu üretim ve tüketim yerlerinde 28 adet gıda maddesinin son kullanma tarihinin geçtiği tespit edilmiştir. Ayrıca 6 adet gıda maddesinin uygun olmayan koşullarda muhafaza edildiği tespit edilmiş ve bu ürünlerde imha edilmiştir. Faaliyet raporunda denetlenen yerlerde tespit edilen en önemli eksikliklerin çalışanların sağlık karnelerinin bulunmaması, gıdaların uygun koşullarda depolanmaması ve son kullanma tarihi geçmiş ürünlerin bulunması, etiketsiz ve tarihsiz ürünlerin kullanılması olduğu ifade edilmiştir (Anonim F, 2020) Ancak faaliyet raporunda bu ürünlerin ve üreticilerin adları yer almamıştır. Tüketicilerin bilinçlenmesi ve teşhir edilmek endişesi ile gıdada hileden kaçınılması adına ürünlerin ve üreticilerin adları ifşa edilmelidir. Türkiye'de 2012-2019 yılları arasında 22 defa kamuoyuna Bakanlık tarafindan açıklama yapılmış ve 1.443 firmanın 3.202 farklı parti ürünü tüketicini bilgisine sunulmuştur (Anonim G, 2020) Ürün Doğrulama ve Takip Sistemine geçilmesi güvenli gıda bakımından doğru bir adım olacaktır. Bu sistem Sağlık Bakanlığ tarafında kurulmalıdır. Bu sistemde tüketiciler Android ve IOS denetim işletim sistemine sahip akıllı telefonlarda yer alan QR karekodu okuma programını ve telefon kamerasını kullanarak gıda ürünü üzerinde barkodu okutabilecek ve uygulama üzerinden o ürüne ait tüm özellikleri, ürün içeriğini ve üretici bilgilerini görebilme imkanına sahip olabileceklerdir (Gıda Gündemi, 2018). Dünyada farklı ürün takip sistemleri bulunmakla birlikte küresel geçerliliği olan uluslararası ölçekte bilgi standartları ortaya koyan ve Birleşmiş Milletler tarafından tavsiye edilen tek izlenebilirlik standardı EAN International (European Article Number) tarafindan oluşturulmuştur. Bu sistem EAN-UCC (Barkod uygulaması) sistemidir (Koç vd. 2008).

Yalnızca denetim mekanizmasının etkin çalışması da tek başına yeterli olmayacaktır. Gıda sektöründe çalışan, tüketici sağlığını yaptığı işin mahiyeti sonucunda direkt etkileyen tüm personelin "gıda güvenliğì" hususunda eğitim almaları önemlidir.

İşletmeler, kendi içerisinde otokontrol sistemi kurarak güvenli gıda üretim proseslerinin etkinliğini gözden geçirmelidir. Belirli periyotlarda hammadde ve ürülerini akredite laboratuar kuruluşlarında analiz ettirerek aldıkları son ürünlerinin yasal şartlara uygunluğundan emin olarak piyasaya sürmelidir. 
Ayrıca basın yayın yoluyla kamuoyunun bilgilendirilmesi büyük önem taşımaktadır. Toplumun bilinçlenmesinde basının büyük etkisi bulunmaktadır. Toplumsal duyarlılığın sağlanması adına basına da büyük görev düşmektedir (Özen, 2016).

Son olarak hileli gıdalarla mücadelede tüketicinin kendi sağlığı için dikkatli olması gerekmektedir. Bu noktada tüketici bilinçli olmalı ve öncelikle kayıtdışı ve izlenebilirliği olamayan ürünlerden uzak durmalıdır. Tüketici izin/kayıt onayı almamış kayıtdışı yani merdivenaltı ürünlerden uzak durmalıdır. Yol kenarlarında, seyyar satıcılar ile kapıya gelen, etiketsiz ambalajlarda "köy ürünü”, “doğal” gibi ifadelerle satılan ürünlerde hileli gıdaların daha ağırlıkta olduğu göz ardı edilmemelidir. Kayıtdışı işyerlerinin denetimsiz olduğu unutulmamalıdır. Organik diye satılan sokak eşyalarına özellikle sütlere dikkat edilmelidir. Sokak sütünün organik diye tüketiciye sunulması ile Brusella zengin hastalığ olmuştur ve bu nedenlerle halk sağlığı açısından büyük bir risk oluşturmaktadır (Anonim H., 2020). Gıdaların etiketlerine dikkat edilmelidir; zira gıdaların nerede, kim tarafından üretildiği, hedef kitlesinin kimler olduğu, parti numarası, menşei, özel tüketim koşulları, alerjen bilgileri gibi pek çok hayati bilgi etiket üzerinde yer almaktadır (Anonim C., 2017).

En önemlisi de piyasadaki fiyatların çok altında pazarlanan ürünlerden uzak durulmalıdır; bir ürünün fiyatı azaldıkça tüketicilerin o gıdada hile yapılmış olması riskinin de arttığını unutmaması gerekir. Kuzey Kıbrıs'da da Türkiye'de olduğu gibi satın aldığı üründen şüphe duyan tüketiciye bilgi vermek üzere ALO Gıda Hattı oluşturulmalıdır.

\section{Kaynakça}

Batu, A., Akbulut, M., Kırmacı, B., Elyıldırım, F., 2007. Üzüm Pekmezi Üretiminde Yapılan Taklit ve Tağşişler Ve Belirleme Yöntemleri, 2007/2, 17-24s.

Doğan, O., 2019. Gıdada Tağşişin Tarihi Ve Politik Ekonomisi Üzerine Bir İnceleme, Toplum Ve Hekim, Temmuz- Ağustos 2019, Cilt: 34, Sayı: 4, 39-54s.

FAO and WHO, 2015. Codex Alimentarius Commission Procedural Manual, Twenty Fourth Edition, ISBN 978 92-5-108928-6, Rome, 231p.

Kantaroğlu, M., Demirbaş, N., 2019. Türkiye'de Gıda Güvenliği Açısından Ürün Doğrulama ve Takip Sisteminin (ÜDTS) Değerlendirilmesi, 498-509s.,

Koç, A., Bölük, G., Aşçı, S., 2008. Gıda Güvenliği ve Kalite Standartlarının Gıda İmalat Sanayinde Yoğunlaşmaya Etkisi, Akdeniz Üniversitesi İktisadi ve İdari Bilimler Dergisi, (16): 83-115.

Moore J. C., Spink, J., Lipp, M., 2012. Development and application of a database of food ingredient fraud and economically motivates adulteration from 1980 to 2010. Journal of Food Science, 77 (4), R118-R126.

Özen, M. 2016. Gıdada Sahtekarlık , Cezai ve Hukuki Sorumluluk, Ankara Barosu, 2016/2, 331 336 s.

Tayyar, M., 2014. Güvenli gıda gereksinimi, Dünya Gıda Dergisi, 2014 (9): 34-37s.

WHO, 2015. WHO estimates of the global burden of food borne diseases. Publications of the World Health Organization.

\section{İnternet Kaynakları}

Gıda Gündemi, 2018, “Karekoddan Sonra ÜDTS”, http://www.gidagundemi.com/gidagundemi/turkiye/karekoddan-sonra-udts-h1720.html (Erişim Tarihi: 5 .02. 2020).

Artık, N. 2020, “Gıdalarda Taklit ve Tağşiş”, https://www.medikalakademi.com. tr/? get_group $\underline{\mathrm{doc}}=18 / 1460214854$-gidalardataklitvetagdis.pdf, (Erişim Tarihi: 7.02.2020).

Anonim A, 2020. ;https://www.tarimorman.gov.tr/Lists/Duyuru/Attachments/1102/Kamuoyu Duyurusu_2020-1.pdf (Erişim Tarihi: 14.01.2020). 
Anonim B, 2010. https://www.dw.com/tr/çinde-yine-melaminli-süt-tozu-skandalı/a-5931946 (Erişim Tarihi: 3.02.2020).

Anonim C, 2017. https://www.facebook.com/gidaguvenligidernegi/posts/1662666887085604/ (Erişim Tarihi: 6.2.2020).

Anonim D, 2019. https://www.haberturk.com/son-dakika-nedeni-ortaya-cikana-kadar-markettenispanak-almayin-haberler-2537316 (Erişim Tarihi: 5.02.2020) .

Anonim E, 2020. https://saglik.gov.ct.tr/DENETIMLER/GIDA-VE-ÇEVRE-SAĞLIĞIFAALIYET -RAPORLARI (Erişim Tarihi: 3.02.2020).

Anonim F, 2020. https://saglik.gov.ct.tr/Portals/107/saglik\%20bakanligi\%202018\%20faaliyet\%20 raporu.pdf?ver=2018-12-14-164305-257 (Erişim Tarihi: 3.02.2020).

Anonim G, 2020. https://www.tarimorman.gov.tr/Konular/Gida-Ve-Yem-Hizmetleri/GidaHizmetleri/Resmi-Kontroller?Ziyaretci=Tuketici,; https://www.tarimorman.gov.tr /Duyuru /1102/ Kamuoyuna-Duyurulur,

Anonim, H, 2020. http://www.gida2000.com/prof-dr-nevzat-artik-sunu-yiyin-bunu-yiyin-diyerekbilimsellik-disinda-yorumlar-yapiliyor.html (Erişim Tarihi: 5. 02. 2020). 